NEWS

\title{
Still strict on stem cells
}

\section{Even some Bush-approved cell lines could be denied federal funding.}

US stem-cell researchers are applauding draft guidelines released by the National Institutes of Health (NIH) last week to govern federally funded research on human embryonic stemcell lines. Some, however, say the provisional rules are still too restrictive because they would exclude lines derived from embryos created for research purposes.

The provisional rules come 39 days after President Barack Obama signed an executive order freeing up federal money for such research. They would limit federal funding to work on stem-cell lines derived from embryos created by in vitro fertilization (IVF) solely for reproductive purposes, and no longer needed for that purpose. Researchers would have to document that parents had voluntarily donated the embryos, without inducements and without researcher influence.

Disappointingly for some researchers, the guidelines explicitly disqualify from funding any stem-cell lines derived from embryos created for research purposes, whether by standard IVF methods or by somatic-cell nuclear transfer. The draft guidelines also forbid funding for lines derived through parthenogenesis, a form of asexual reproduction in which an unfertilized egg is developed into an embryo.

The guidelines, if adopted as issued last week, could create an immediate problem for researchers already working on the score of lines approved for federal funding in August 2001 by former president George W. Bush. Of those lines, "not all are likely to be eligible for continued federal funding" under the new draft guidelines, says Thomas Murray, president of the Hastings Center, a bioethics think tank in Garrison, New York. "I would counsel the NIH to consider creating an exception for these cell lines if they continue to have very significant scientific value," he says.

Others go further. The agency's informed consent requirements are "fine going forwards. But I think they are going to have to loosen those expectations a little bit for [all] preexisting lines," says Sean Morrison, director of the University of Michigan Center for Stem Cell Biology in Ann Arbor.

The NIH is publishing its proposed guidelines this week in the Federal Register, kicking off a 30-day public comment period. It has until 7 July to finalize the guidelines.

"This represents a great expansion in opportunity for scientists doing research in this field," says Raynard Kington, acting director of the agency based in Bethesda, Maryland. Defending its decision to exclude lines derived from embryos created for research purposes, he says: "We don't believe that there is yet even consensus within the scientific community that would

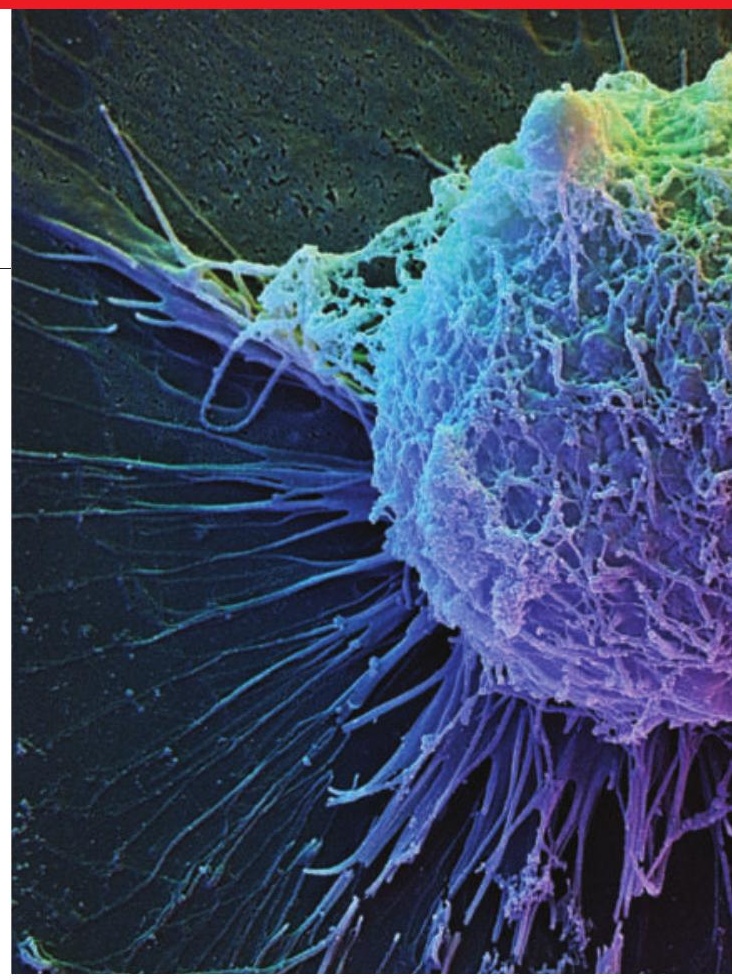

An embryonic stem cells - made to be born?

warrant going to the next step."

Once the guidelines are finalized, the agency will periodically revisit them to see if adjustments are needed to reflect evolving science.

The NIH estimates that more than 760 human embryonic-stem-cell lines exist, and Kington says he expects "many" will meet the final eligibility standards.

Review and funding of current applications for stem-cell research proposals will be deferred until the final guidelines are issued. At that point, researchers will have the opportunity to modify their applications to comply with the guidelines before funding decisions are made.

\section{Pharmaceutical companies join forces on HIV}

GlaxoSmithKline (GSK) and Pfizer plan to merge their HIV drug divisions in an unusual move designed to shore up their poor market positions. The marriage will create a new company, yet to be named, which will use the existing research and market portfolios of the parent companies to develop new combination drugs, the mainstay of HIV treatment.

"The fact that GSK needs a partner reflects its weakness in this market," says Holger Rovini, an analyst at consultancy Datamonitor Healthcare in London. Although London-based GSK has a much greater share of the anti-HIV drug market than Pfizer, its drugs are nearing patent expiration and sales are slowing. Pfizer, based in New York, has a smaller market presence, but owns a healthier pipeline of candidate HIV drugs.

The venture will start with a $19 \%$ share of the US\$12.3-billion global HIV treatment market and a pool of 17 drug entities - including six new molecules - to trawl for new combinations. It will carry out HIV drug discovery by contracting out from GSK and Pfizer's in-house research and development arms, and will be able to negotiate exclusive rights to any new HIVrelated compounds developed by either company. The venture will also be free to seek out its own research and licensing deals from other companies.
A key benefit for the parent companies is that they will share the risk of pipeline drugs failing and get ready access to new compounds. GSK will own $85 \%$ of the shares in the new company, with Pfizer taking the remaining $15 \%$. Profits from fruitful combinations would be shared as company stock, with a weighting applied depending on which parent company provided the active compounds.

The new company will be hoping to create a drug combination to rival the blockbuster anti-HIV combination Atripla, created by teaming two drugs made by Gilead Sciences of Foster City, California, with efavirenz, a compound owned by New York-based Bristol-Myers
Squibb. Approved by the US Food and Drug Administration in 2006, Atripla marked the first time that anti-HIV drugs owned by different companies had been united into a single product. The combination helped to push Gilead's worldwide sales of HIV drugs to US $\$ 4.3$ billion last year, almost double GSK's HIV drug sales of $\$ 2.4$ billion.

The GSK-Pfizer venture reinforces the importance of sharing intellectual property to tackle HIV, says Ellen 't Hoen, a senior adviser on intellectual property at UNITAID, an international drug-purchase facility hosted by the World Health Organization in Geneva, Switzerland. 't Hoen is leading 
